Proc. Estonian Acad. Sci. Eng., 2004, 10, 1, 39-44

\title{
Testing hardened steel targets for dynamic hardness
}

\author{
Ilmar Kleis and Toomas Remi \\ Department of Mechatronics, Tallinn Technical University, Ehitajate tee 5, 19086 Tallinn, Estonia; \\ ikleis@staff.ttu.ee, toomas.remi@baltilaager.ee \\ Received 17 March 2003, in revised form 8 May 2003 \\ Abstract. In literature no information can be found about any recognized method of testing steels \\ harder than $350 \mathrm{HV}$ for dynamic hardness, neither about its numerical values for different steels, \\ needed for the prediction of erosion resistance of steels. This paper represents a new method for the \\ determination of dynamic hardness properties of hard materials and discusses the test data obtained \\ on steels with hardness range of 360-820 HV.
}

Key words: hardened steels, dynamic hardness, dynamic-to-static hardness relationship.

\section{INTRODUCTION}

In general, hardness is a significant characteristic of a material and its applicability for specific purposes. The widely used hardness testing methods (Brinell, Rockwell, Vickers) are based on the principle of determining the ability of the material surface to resist plastic deformation or penetration of an indentor under static load. However, remarkable growth of interest to the problems of dynamic hardness started when the dependence of most mechanical properties of metals on the loading rate was established. This phenomenon was discovered in 1872 by Hopkinson who proved that a steel wire, subjected to short-time pulse loading in tension, can resist considerably higher stresses than under static load [ $\left.{ }^{1}\right]$.

At the beginning of the 20th century, Class and Schwarz published reports on studies conducted with steel balls, employed as indenting bodies at impact velocities up to $10 \mathrm{~m} / \mathrm{s}$. They concluded that the dynamic hardness of metals is remarkably higher than the static one $\left[^{2}\right]$.

At this period, it was believed that the most expedient criterion to estimate dynamic hardness is the specific energy of crater formation in the surface layer, 
i.e., the kinetic energy consumed to produce a unit volume of indentation, thus neglecting the stress required for penetration. This idea was first suggested by Martel in 1895 and later in 1920 supported by Wüst and Brandhauer $\left[{ }^{2}\right]$.

Analysing the volumes of segmental impact scars together with the values of kinetic energy consumed for their formation as reported by various authors, a hypothesis on the constancy of specific energy of indentation was postulated $\left[^{3}\right]$. It was claimed that independently of the origin of the impact indentation (elastoplastic and viscoplastic deformation, melting or sublimation of metal by hypervelocity impact), the amount of kinetic energy required to produce a unit volume of impact crater is the same.

In $\left[{ }^{4}\right]$, describing experiments carried out with spherical projectiles at impact velocities between 10 and $230 \mathrm{~m} / \mathrm{s}$, the results obtained on pure metals indicated that specific energy depends on the type of crystal lattice reaching its maximum with BCC and minimum with FCC and HCP lattice.

In all the above tests, target materials under study were ductile metals and mild steels soft enough for using indentors of hardened steel $\left[{ }^{5}\right]$. With further progress of the erosion science it became necessary to study the behaviour of metals in a harder condition, e.g., quenched or tempered steels for which appropriate indentors of no less than $1000 \mathrm{HV}$ are required. Since for this case almost no data can be found in the available literature, the present paper is aimed to filling the existing gap in the theory.

\section{TESTING PROCEDURE AND RESULTS}

Most suitable indentor material is cermet, viz a sintered tungsten-base hard carbide with cobalt binder and prevailing hardness of $1050 \mathrm{HV}$ combined with the required impact toughness. For the acceleration of the indentors, an air pistol and an air gun, both with overbored (ungrooved) barrels were employed (Fig. 1). Bullets of various length and mass (1.95 to $3.15 \mathrm{~g}$ ) were used. Testing scheme is shown in Fig. 2.

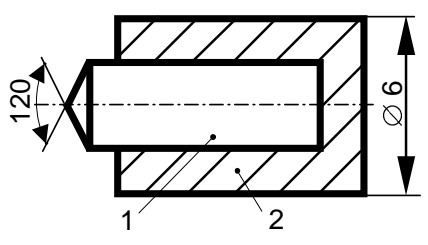

Fig. 1. Bullet for acceleration: 1 $\varnothing 3 \mathrm{~mm}$ cermet indentor; 2 - copper shell.

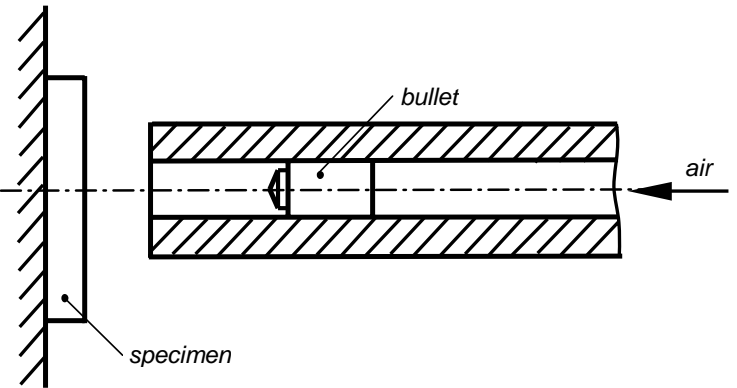

Fig. 2. Acceleration of bullets with an air gun. 
Quenched steel specimens of 4 to $8 \mathrm{~mm}$ thickness, tempered to various hardnesses were glued to a heavy $(30 \mathrm{~kg})$ steel block. Specified data on the steels tested are presented in Table 1 , where $H_{\mathrm{V}}$ denotes Vickers hardness. Impact craters, which appeared on the polished surface of the specimen, were examined under the NIKON SMZ 800 microscope. A typical section of the impact indentation is shown in Fig. 3.

By computing the volume of a conical impact crater, its actual shape was taken into account keeping also in mind elastic recovery of the material, increase of the cone apex angle to $128^{\circ}$, and bottom rounding.

For determining the bullet velocity, the classical ballistic pendulum method was employed (Fig. 4).

A spherical plasticine bob of mass $m_{2}=16 \mathrm{~g}$ (in air pistol tests) or $m_{2}=30 \mathrm{~g}$ (in air gun tests) was suspended by a thin cord of $650 \mathrm{~mm}$ length. Ballistic swing of the pendulum was recorded by means of a CCD-TR918E video camera.

Using the notations shown in Fig. 4, we can write

$$
m_{1} v_{1}=\left(m_{1}+m_{2}\right) v_{2}, \quad v_{2}=m_{1} v_{1} /\left(m_{1}+m_{2}\right) .
$$

Table 1. Characteristics of the tested steels

\begin{tabular}{l|l|c|c|c|c|c|c|c|l}
\hline \multirow{2}{*}{$\begin{array}{c}\text { Designation } \\
\text { of the steel }\end{array}$} & \multicolumn{7}{|c|}{ Chemical composition, \% } & \multirow{2}{*}{$H_{\mathrm{V}}, \mathrm{GPa}$} & Remarks \\
\cline { 2 - 8 } & $\mathrm{C}$ & $\mathrm{Si}$ & $\mathrm{Mn}$ & $\mathrm{Cr}$ & $\mathrm{Mo}$ & $\mathrm{V}$ & $\mathrm{W}$ & & \\
\hline Arne & 0.95 & 0.3 & 1.1 & 0.6 & & 0.1 & 0.6 & $3.6-6.9$ & Uddeholm \\
Calmax & 0.6 & 0.35 & 0.8 & 4.5 & 0.5 & 0.2 & & $3.7-5.2$ & Steelworks, \\
Rigor & 1.0 & 0.3 & 0.8 & 5.3 & 1.1 & & & $3.8-4.9$ & Sweden \\
XВГ & 1.0 & 0.2 & 0.9 & 1.0 & & & 1.5 & $5.5-8.0$ & Russian \\
У8A & 0.8 & 0.2 & 0.2 & 0.1 & & & & $5.6-6.3$ & steels \\
45 & 0.44 & 0.2 & 0.7 & 0.15 & & 0.02 & & $4.7-6.5$ &
\end{tabular}

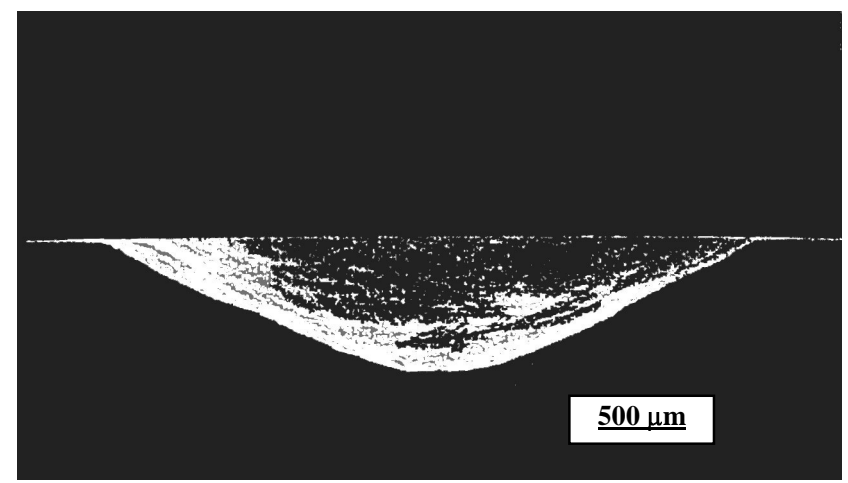

Fig. 3. Microsection of the impact crater on specimen surface. Bottom radius, formed by the indentor tip, is $0.45 \mathrm{~mm}$. 


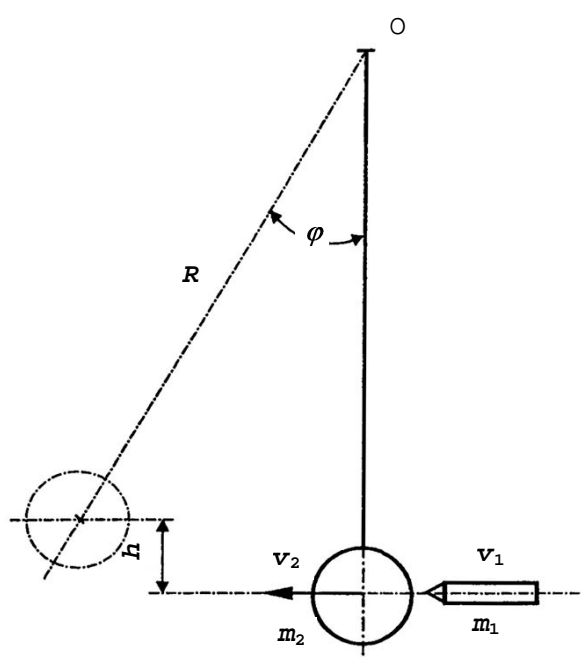

Fig. 4. Scheme of the ballistic pendulum.

In the course of the pendulum movement off the neutral position its kinetic energy $0.5\left(m_{1}+m_{2}\right) v_{2}^{2}$ is converted into potential energy $\left(m_{1}+m_{2}\right) g h$, where $h$ depends on the angle of pendulum inclination $\varphi$.

Consequently

$$
0.5\left(m_{1}+m_{2}\right)\left[m_{1} v_{1} /\left(m_{1}+m_{2}\right)\right]^{2}=\left(m_{1}+m_{2}\right) g h,
$$

and

$$
v_{1}=\left[\left(m_{1}+m_{2}\right) / m_{1}\right](2 g h)^{0.5}=\left[\left(m_{1}+m_{2}\right) / m_{1}\right]\left[(2 g R(1-\cos \varphi)]^{0.5} .\right.
$$

Kinetic energy $W$ of the bullet is expressed as

$$
W=0.5 m_{1} v_{1}^{2}=g R\left(m_{1}+m_{2}\right)^{2}(1-\cos \varphi) / m_{1} .
$$

In most cases two bullets of different mass, 1.95 and $3.15 \mathrm{~g}$, were used. When shooting them with the air pistol, the value of $W$ obtained was found to be $1.4 \mathrm{~J}$, whilst with air gun the result was $2.5 \mathrm{~J}$. The respective impact velocities ranged between 29.8 and $50.6 \mathrm{~m} / \mathrm{s}$.

Results of the experiments are shown in the diagram (Fig. 5), representing the desired relationship between dynamic and static hardnesses of the target material. Each point shown in this graph corresponds to the arithmetical mean value of three test results.

It can be seen in Fig. 5 that independently of the composition of the target material, impact velocity, and mass of the bullet, the test points lay rather closely near a straight line described by the equation

$$
e_{0}=1+H_{\mathrm{V}}, \mathrm{J} / \mathrm{mm}^{3},
$$

where $H_{\mathrm{v}}$ is the static hardness of the steel in GPa. 


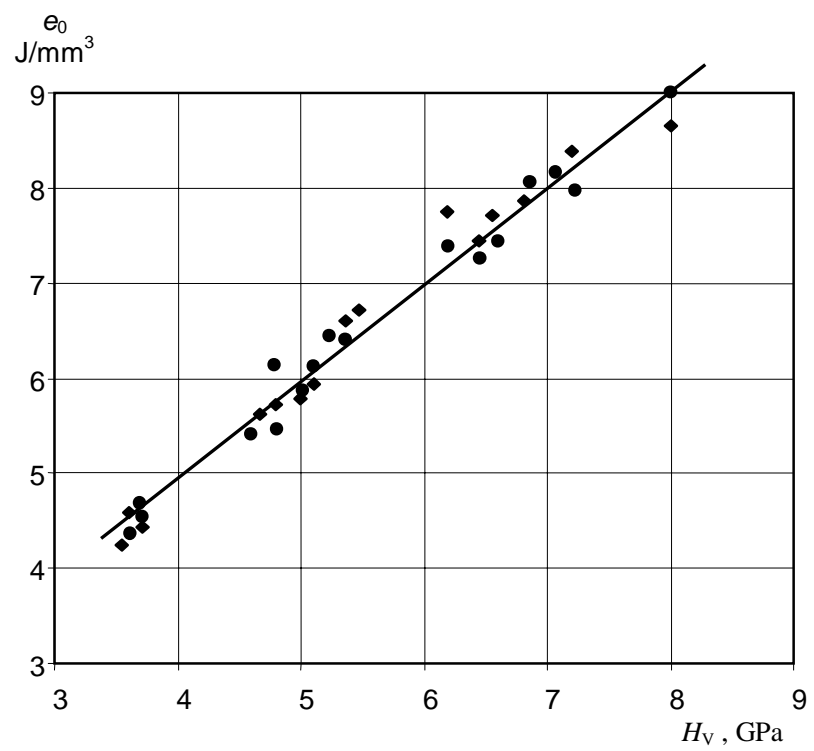

Fig. 5. Dependence of dynamic hardness $e_{0}$ on static hardness $H_{\mathrm{V}}: \bullet-$ test points obtained with air pistol; - test points obtained with air gun.

In comparison with ductile steels (of $H_{\mathrm{V}}$ below 250) whose dynamic hardness is nearly twice the static one, we have established that this is not the case for hardened steels, which exhibited almost no difference. Thus, as a first approximation, dynamic hardness of steels within the range of 360 to $820 \mathrm{HV}$ can be regarded equal to the static hardness.

\section{CONCLUSIONS}

1. A new method for experimental determination of the dynamic hardness of hardened steels, applicable to the range of impact velocities from 30 to $50 \mathrm{~m} / \mathrm{s}$, has been proposed.

2. As opposite to the behaviour of ductile metals, the difference between dynamic and static hardnesses of hardened steels is negligible.

3. An empirical expression has been suggested, which establishes the relationship between dynamic and static hardness and can be used for the purpose of erosion prediction on the basis of the energetic theory of erosion.

\section{ACKNOWLEDGEMENT}

This work was supported by the Estonian Science Foundation (grant No. 4267). 


\section{REFERENCES}

1. Rinehart, J. S. and Pearson, J. Behaviour of Metals under Impulsive Loads. The American Society of Metals, Cleveland, 1954.

2. Davidenkov, N. N. Dynamic Testing of Metals. Gosizdat, Moscow, 1929 (in Russian).

3. Kleis, I. R. Hypothesis on the constancy of energy required to produce an impact crater in metal target surface. Proc. Tallinn Polytechnical Institute, 1978, No. 455, 3-8 (in Russian).

4. Kleis, I. R. and Kangur, H. E. Resistance of metal surface to indentation by spherical projectile at impact. In Proc. of 7-th Conference on Erosion by Liquid and Solid Impact. Cambridge, 1987, 48.1-48.7.

5. Kleis, I. R. and Remi, T. M. On the geometry of impact craters produced by indentors of different shape. Proc. Tallinn Technical University, 1991, No. 728, 3-7 (in Russian).

\section{Karastatud teraste dünaamilise kõvaduse määramine}

\section{Ilmar Kleis ja Toomas Remi}

Seni puudub üldtunnustatud meetod kõvadusega HV $>350$ teraste dünaamilise kõvaduse määramiseks, samuti puuduvad andmed selle näitaja numbriliste väärtuste kohta. Vajadus selle järele seostub eelkõige teraste erosioonikindluse hindamisega. Artiklis esitatakse uus materjalide dünaamilise kõvaduse määramise meetod ja tuuakse katsetulemusi terastega kõvaduste vahemikus 360$820 \mathrm{HV}$. 